\title{
STATE AND RELIGION IN A SECULAR SETTING: THE TURKISH EXPERIENCE
}

\author{
ÜMIt CizRE-SAKAlliơlu*
}

The contention of this paper is that, throughout the republic, the single most important determiner of the role, relevance and importance of religion in politics has been the state rather than the initiative of the religious forces themselves. Put differently, it is how the state élite has acted and reacted towards religion which has structured the political options, venues and discourses open to political Islam, and the degree to which religion could pose a challenge to the secular basis of the regime. This determining role of the state, has in turn, been a historical product of the conditions surrounding the formation and the evolution of a

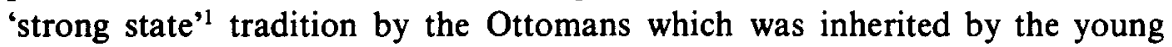
republic. In this sense, this paper upholds the perspective that how regimes are born set the parameters for subsequent developments, and that, in the Turkish case, there has been more of the element of 'continuity' than change with regard to the powerful role the state has played in its relationship with religion. In my opinion this aspect of continuity applies up to the point of writing the paper, despite the seeming change in the contours of the state-religion relationship after the 1980 coup, which, as will be argued, was also a result of the changing political conditions.

There is no denying however, that the maintenance of a strong state tradition in religion has gone through different historical phases, each with different set of constraints.

\section{THE MONO-PARTY PERIOD: THE SOCIO-CULTURAL TRANSFORMATION PROJECT}

The mono-party period of the early republic which lasted from the inception of the regime in 1923 until the gradual spread of multi-party politics in 1946, was the immediate heir to not only many of the intellectual and institutional traditions of the Ottomans, but also to a structure of society and religion and to a model of state-society interaction which was responsible for a particular type of state hegemony over Islam. In order to discuss the Ottoman legacy with respect to this model of hegemony in the republic, let us only examine two relevant aspects of Ottoman statecraft.

First, Islam occupied its due place both in the structuration of the central government and the society. This broad division between state and society is conceived to be mainly a cultural cleavage ${ }^{2}$ between a 'centre' based on shari'a, and a 'periphery' where religion took the form of 'folk' Islam, depending on membership in local religious orders, sects, or cults. The Ottoman centre, from

*Department of Political Science and Public Administration, Bilkent University, 06533 Ankara, Turkey. 
the very beginning, managed to have complete control over both the highranking religious functionaries - the ulema-within the state apparatus, and over the folk Islam. The end result was that, although there is no doubt that Islam constituted part of state mechanism and legitimation, at the same time however, the shari'a based Ottoman state was never as Islamic as, for example, the present Iranian Islamic republic is, ideologically, structurally and policywise. The outstanding reason for this was the constraints of ruling a multi-religious empire. If the shari'a basis of the state had been overemphasised, this would have provoked the reactions of the non-Muslim religious communities, organised around the 'millet' system, and also of the minority Muslim sects, like the Ottoman Shi'ites, and would endanger the unity of the Empire. If, however, control over the practices and institutions of Muslim religion had been relaxed, that would again lead to disastrous consequences for the legitimacy of the centre. There was, in short, a real fear by the state of religion as a force capable of making or breaking the Empire. The preferred solution was to impose political and bureaucratic controls over a weakly organised religious hierarchy-the ulema.

Second, since religiosity among the common people took a diversity of forms, the structure of religion on the periphery also facilitated its containment by the centre. Though reducing the impact of folk religion on the central administration, the fragmentation of religiosity did not however stop the periphery from rebelling against the series of secular reforms undertaken in the Empire beginning from the end of the eighteenth century, stretching into the Young Turk period in the first quarter of the twentieth. These reforms were initiated by the Ottoman state to counter the problems of decline and disintegration.

There is no reason to suppose that the nation-building and state-making civil and military élite of the infant republic did not face the same constraints which the reforming young Turk élite of the Ottoman centre did. After all, there was continuity not only in the way social change-Westernisation-and the obstructionist role of religion were conceived by the Young Turks and Kemal Atatürk, founder of the republic; but also in the way Islam challenged the secularist moments and movements by rallying discontent and opposition to the state around itself. Thus, despite the secularisation of state, came the establishment of an official religious establishment in the form of a subordinate government agency, for achieving what the Ottoman state sought to achieve: the integration of Islam under the wings of the strong state so as to control it.

What factors were instrumental in making this control over religion indispensable, despite the break with the Ottoman state on the shari'a basis of state? The answer must also partly lie within the nature of this rupture with the past, which consisted of two gigantic packages. The first was a cultural project concentrating intensively on the micro parameters on the level of the attitude of the individual. It was hoped that by secularisation, religion would not be compromised at the everyday level, and thus the individual would be relieved of the oppressive constraints of Islam-as-culture in his own home and community, turning into a new man type ${ }^{3}$ conducive to sustaining the new goal of the state: modernisation on westernised lines. Here, one can easily detect the same old fear of folk Islam organised around a multiplicity of orders, sects, cults, sheikhs and what not, posing a mentality threat to the young republic. The second radical 
rupture with the past was composed of three dimensions, all political in nature: nation-building, state-formation and political consolidation. In the attainment of all these three tasks, the official ideology of the republic, called Kemalism, continued to manifest the elements of the authoritarian traditional culture of the Ottomans in that it took the sole initiative in dominating, structuring and organising sources of national identity, social cohesion, political unity and state structure, admittedly along a westernisation model.

Let us look at this political package more closely. In establishing secularism as the pillar of the cultural and political transformation of the society, the Kemalist élite had the sole power of designing, redefining and superseding all the elements which represented a threat to the three tasks listed above. In other words, the State would overwhelm anything that stood on its way to nation-building, stateformation and establishing its political hegemony over the populace. The divisive potential of social class, religion, sectarianism and ethnicity were to be ruled out, by setting up a corporate society based on a system of close vigilance by the state, rather than by following a policy of accommodation.

At the time of the founding of the republic, none of these public enemy social actors however, posed as powerful a threat as religion. Secularisation involved a headlong clash with the very raison d'être of Islam which claimed superiority in forming and sustaining a state on Islamic maxims. Now, the basis of legitimacy of political power was shifted from Islam to electoral mechanisms, which would later, in a more competitive period, turn into a more developed concept of popular sovereignty. It is only through this tenuous link that Turkish secularism became a codeword for democratisation. However, the precariousness of this link was soon proven by the looming problem of political consolidation which necessitated controlling, structuring and co-opting the traditional elements on the periphery entering into the political system via the formula of universal suffrage.

In the formative years of the republic, and for that matter, for years to come, the new Turkish state therefore, both controlled and co-opted and at the same time set the tone of the religious dissidence. While the moral outrage in the countryside to the twofold package of cultural Westernisation and political integration produced the conditions conducive to anti-secular movements, ${ }^{4}$ the Ankara government, under the influence of the accumulated wisdom of the Ottoman experience took its guard: in the name of secularisation, it created a state department which enabled it to have a say in religious affairs without itself making any attempt to create a new version of Islam. The strange and unique features of institutionalising Islam in a predominantly Muslim society were reflected in the state élite not intending to separate the temporal and spiritual realms the way the Biblical maxim put it: "render unto Ceasar that which belongs to Ceasar, and unto God that which belongs to God'.

\section{RELIGION AND STATE IN THE MULTI-PARTY PERIOD: THE ELECTORAL CONSTRAINTS OF THE 1950s}

The success record of Turkish secularism, in the mono-party period, in excluding Islam from the political sphere and from undermining the Westernisation process in the political sphere is impressive. ${ }^{5}$ So much so that the 
political opposition on the periphery, taking the form of religious rebellions, had neither the vision, nor the power to organise an effect assault on Kemalist secularism. In the aftermath of the Second World War, the changing balance of social forces within the country and also in the Western bloc hastened the introduction of competitive party politics. In 1950, a new political party on the centre right spectrum, the Democrat Party (DP), claiming to represent the periphery was elected to power and stayed there until overthrown by the military coup of 1960 . When the overall record of the party on the issue of religion is set against the achievements of the previous era, it can easily be asserted that since in major ways the DP shared the same commitment with the Kemalist state elite to modernisation via the secular route, the civil-military bureaucracy continued to keep a tight rein over religion. This is so, despite the fact that for more instrumental than ideological reasons, the party set the precedence for Turkish political parties to mobilise the religiosity of the rural voters for political gain. This is also what forms the basis of the claim made by some Western observers that the $1950 \mathrm{~s}$ are to be characterised as a decade of religious revival and resurgence. ${ }^{6}$ However, DP's promotion of religion for electoral success was due to the necessities of party politicking under the conditions of the 1950s: lacking a previously cultivated power base at the grass roots, or in the bureaucracy by patron-client network, it is not surprising that the DP discovered religion and employed it.

\section{THE 1970s: THE STATE AND THE COURSE AND DISCOURSE OF RELIGION}

In many ways, the first military coup of the Turkish republic in 1960, represents a watershed on the Turkish political landscape, particularly for Islam. In the more liberal and pluralist orientation of the era, and under the impact of the exceptionally rapid socio-economic modernisation of the $1960 \mathrm{~s}$, the old cultural cleavage between the state and society turned into a left-right division with fragmentation and radicalism in each camp leading to political violence and the collapse of the political system. The first pro-Islamic party of the period, the National Salvation Party (NSP), was formed in this more permissive and democratic climate, and became a key coalition partner between 1974 and 1977, despite its known espousal of anti-Kemalist and anti-systemic tendencies.

The emergence and the operations of the NSP reaffirms, rather than invalidates, our basic proposition that it has always been the state which has steered the political course and the discourse of religion as an oppositional force. The civil-military bureaucracy, with their self-defined role as the guardians of the public interest, though disliking the NSP, were not unduly alarmed by the activities of it, as long as the party did what it had been doing: officially supported secularism, paid homage to the principles of parliamentary democracy and political pluralism, and did not get involved in political violence. This tacit pact suited the NSP much more than the secular élite, since it based its strategy not on short-term electoral gains but on the long-term goal of promoting the role and relevance of Islam in Turkish politics. The precondition to do this was to wage the struggle from within the secular state, from a legitimate place and 
through a legitimate form of organisation, a modern political party. In any case, unofficially, the party adopted an opposite discourse to the one it employed in front of the Kemalist public.

On another level too, the rise, the social base and the programmatic vision of the party emphasised the determining role of the state. The standard argument explaining the political fortunes of the party links it with the dislocations caused by the unevenness of capitalist development and thus classifies it as a typical example of Islam-as-a-rallying-platform-of-discontent for those small traders and artisans who do not get full benefits from capitalism. Despite the element of truth in it, this view point must be complemented by another one: the NSP can be interpreted as a clear sign of the success of the Kemalist drive for a modern and secular education system which was responsible for the creation of very many aspirations unmet by prayers and rituals. As an Islamist party, born into the age of modernisation and welfare capitalism, it is not surprising therefore that the party articulated a double discourse: ${ }^{7}$ with its advocacy of a return to strict Islamic polity in terms of moral and religious values, it appealed to the traditional elements; whereas with its pro-industrialisation and pro-technology bias it opened its doors to the 'modern' aspirations of Islamists educated in secular institutions, thus proving itself capable of rethinking modernity in the light of Islamic maxims, a process, definitely taken up and elaborated further by the upcoming radical Islam.

\section{THE CONTRIBUTION OF THE STATE TO THE DESTABILISING EFFECT OF ISLAM IN THE POST-1980s}

The tide of Islamic extremism in the post-1980 era should be seen neither as a pure revival nor a simple continuity of Islam in accordance with the precedence set by the 1950s and then the 1970s; since no degree of accumulated grievances by which the past two waves are explained, can provide the present momentum for the movement. Nor is this a replica of what is happening elsewhere in the Muslim world. It is our proposition that the vigour and the dynamism of the movement, once more, owes more to the actions and doings of the post-1980 state than to the seeds sown in the past.

There are at least three fundamental reasons that were instrumental in the promotion of the Islam factor by the state élite, both during the military (1980-1983), and the subsequent period of civilian rule. To begin with, the near civil-war situation of the country on the eve of the 1980 coup convinced the military and its civilian allies that the failure of political pluralism reaffirmed their belief that the communist menace was a thousand times worse than religious obstructionism and reaction. Thus came the policy of reconciliation, recognition and tolerance towards religion in order for it to act as a bulwark against communism. Secondly, the post- 1980 period was also a serious phase of transition from republic-old etatist economic development model to a liberal economy one. One political condition for the success of the bitter medicine made necessary by the structural adjustment of the Turkish economy was the creation of a socially disciplined and thus politically-stable society where the people would bear the sacrifices needed to uphold a free-market oriented economy. 
Islam was therefore utilised by the state élite to dampen the explosive impact of competitive capitalism.

Last, but by no means the least, the articulation of Islam into the Kemalist discourse was, in part, due to the rising crest of religion as a viable ideology all around the Middle East, even in the Far East, and among the Muslim residents in the West. Faced with this reality, the state élite tried to pre-empt this spreading radicalism by emphasising their own commitment to religious orthodoxy, thereby missing the crucial point that the Islam they were dealing with was neither the mild Islam prevalent among the masses, nor controllable like the NSP's.

To sum up, due to its strong state tradition, the Turkish state has achieved producing two antithetical developments: it has subordinated and marginalised religion in the political sphere, and thus caused it to act as a destabilising force. Nevertheless, the state has shown a remarkable capacity and effectiveness in containing, manipulating, or if the worst comes, co-habiting with Islam, which not only distinguishes her from the neighbouring Middle Eastern States but also provides fresh hopes for the future fate of the secular republic.

Bilkent University, Ankara

Ümit Cizre-Sakallioğlu

1. Metin Heper, 'Extremely 'Strong State' and Democracy: the Turkish Case in Comparative and Historical Perspective', paper presented at the Colloquium, 'Democracy and Modernity, the Israel Academy of Sciences and Humanities, Jerusalem (5-6 January 1987), p. 2. Here, strong state is defined not only by classical standards, i.e. by its autonomy from political and social and obviously religious units in the civil society, but by an additional criteria: by a self-defined role of the state as guardians of public interest. Since this sets the Ottoman and the Turkish case apart from the political developments occurring elsewhere in the Third World, which are inimical to democracy; and despite the problem of authoritarianism which this state is prone to, the concept is conceived by Heper as a positive 'formula' preventing Turkey from drifting into a 'long-lasting' authoritarianism, pp. 2-3. The same conclusion is more or less reached in this paper with regard to the more specific problem of strong state effectively barring the destabilising effects of the revolutionary potential of Islam against the secular basis of the society.

2. Serif Mardin, 'Center-Periphery Relations: A Key to Turkish Politics', in Engin Akarli and Gabriel Ben-Dor (eds), Political Participation in Turkey (Istanbul: Bogazici Üniversitesi Yayinlari, 1975), pp. 7-20.

3. Serif Mardin, 'Religion and Secularism in Turkey', in Ergun Özbundun and Ali Kazancigil (eds), Atatürk, the Founder of a Modern State (London: C. Hurst and Company, 1981), pp. 213-.217.

4. Serif Mardin, 'Culture and Religion: Toward the Year 2000', in Turkey in the Year 2000 (Ankara: Turkish Political Science Association Publication, 1989), p. 171.

5. George Harris, 'Islam and the State in Modern Turkey', Middle East Review, 11 (Summer 1979), p. 21.

6. For a representative sample of this approach see Bernard Lewis, 'Islamic Revival in Turkey', International Affairs, 28 (1952), pp. 38-48; and Howard A. Reed, 'Revival of Islam in a Secular Turkey', The Middle East Journal, 8 (1954), pp. 267-282.

7. Ergun Özbundun, 'Islam and Politics in Modern Turkey: the Case of National

History of European Ideas 
Salvation Party', in Barbara Freyer Stowasser (ed), The Islamic Impulse (London, Sydney: Croom Helm, 1988), p. 146; Türker Alkan, 'The National Salvation Party in Turkey', in Metin Heper and Raphael Israeli (eds), Islam and Politics in the Modern Middle East (London, Sydney: Croom Helm, 1984), p. 86. 